\title{
Parasitoids of Quinoa Moth: Eurysacca Melanocampta Meyrick (Lepidoptera: Gelechiidae) in Eight Locations of Cusco, Peru
}

\author{
Erick Yábar-Landa and Juan F. Costa
}

\begin{abstract}
The presence of six genera of parasitoid insects of quinoa moth larvae: Eurysacca melanocampta Meyrick (Lepidoptera: Gelechiidae) in eight locations of Cusco is reported. The genera recovered are: Apanteles, Bassus, Bracon and Macrocentrus (Hymenoptera: Braconidae), Diadegma (Hymenoptera: Ichneumonidae) and Phytomyptera (Diptera: Tachinidae). The species Apanteles sp. and Phytomyptera sp. were found in all the visited location. The greatest diversity (Simpson 1-D) was observed in Izcuchaca (Anta province) followed by Quiquijana and Maranganí (Canchis province). The structure of the parasitoid communities is different for each evaluated location.
\end{abstract}

Index Terms - Quinoa, biological control, ecology, community of parasitoids.

\section{INTRODUCTION}

Quinoa is a food crop by excellence; the plant is fully used and has a wide adaptation to various agroecological conditions. It is considered the most complete food for human nutrition [1]. One of the most important pests in the cultivation of quinoa is the "quinoa moth": Eurysacca melanocampta Meyrick (Lepidoptera: Gelechiidae). Two species of the genus Eurysacca are known for attacking the quinoa crop in Peru and Bolivia: E. melanocampata and $E$. quinoae Povolny (Lepidoptera: Gelechiidae), which cause considerable economic losses [2].

Several studies were conducted on pests and their natural enemies in different countries. In Cusco (Peru), Phytomyptera sp. (Diptera: Tachinidae) was reported as one of its most important parasitoids, together with Apanteles sp. and Earinus sp. (Hymenoptera: Braconidae), Diadegma sp. (Hymenoptera: Ichneumonidae) and an undetermined Chalcididae, in addition, differences in the percentage of parasitoidism were found in two locations: Quiquijana (Canchis province) and Izcuchaca (Anta province) [3]. Additionally, for the center of Peru, both species of Eurysacca were reported as main pest of quinoa crop, and an undescribed species of Phytomyptera were reported as its most important parasitoid. Significant differences were found in the levels of parasitoidism between Puno (southern Peru) and Huancayo (central Peru) [4]. In a study carried out at several locations in Bolivia, several species were reported

Published on October 15, 2020.

E. Yábar-Landa, Laboratory of Entomology, Universidad Nacional de San Antonio Abad del Cusco (UNSAAC), Cusco, Perú.

(e-mail: erick.yabar@ unsaac.edu.pe)

J. F. Costa, Laboratory of Entomology, Universidad Nacional de San Antonio Abad del Cusco (UNSAAC), Cusco, Perú.

(e-mail: juan.costa@unsaac.edu.pe) as natural enemies of quinoa moth, including Phytomypetra sp. (Tachinidae: Diptera), a robber fly (Asilidae: Diptera), two species from Carabidae (Coleoptera), parasitoid wasps from Encyrtidae, Ichneumonidae and Braconidae (Hymenoptera) by [5]. Several parasitoid species on $E$ quinoae larvae are also mentioned: Copidosoma sp., Deleboea sp. and Diadegma sp., Phytomyptera sp., Meteorus sp., and Apanteles sp. in all regions where quinoa is grown, with different levels of parasitoidism [6]. The natural enemies associated with the quinoa crop, in Tucumán (Argentina), were reported, for example: Chrysoperla externa and C. argentina (Neuroptera: Chrysopidae), Eriopis connexa, Eriopis sp., Hippodamia convergens (Coleoptera: Coccinellidae), and parasitoids such as Copidosoma sp. (Hymenoptera: Encyrtidae), and one of both undertermined Ichneumonidae and Tachinidae. The species studied are distributed differentially throughout the crop cycle [7].

In Cusco, it has been found that two varieties of quinoa show marked interactions with different species of pests and natural enemies, possibly due to the content of saponins; the species Aphidius sp. and Lysiphlebus sp. (Hymenoptera: Braconidae), $H$. convergens and E. connexa, Araneae and an undetermined Syrphidae, showed fluctuations during the growing season [8].

From the consulted literature, some fundamental aspects are evident: i) more or less dispersed information about the parasitoid species that attack the quinoa moth larvae (regardless of their taxonomic position), ii) marked differences between the composition of beneficial insects between different locations and varieties, iii) marked differences between the levels of parasitoidism between locations. The objectives of the present study were: a) to update the information on parasitoids of the quinoa moth, and b) to assess the differences between parasitoid communities of the quinoa moth in eight locations of Cusco.

\section{MATERIALS AND METHODS}

\section{A. Locations}

Eight locations were selected, corresponding to five provinces located between 3096 and 3975 meters above sea level (Table I).

\section{B. Sampling}

Each location was visited once during the crop development period, especially in the stages corresponding to branching and milky grain. At each visit, 25 plants were evaluated at random, trying to cover the entire field sown. 
Larvae of the quinoa moth (E. melanocampta) were collected by shaking the panicles on a plastic tray. The larvae were taken to the laboratory and conditioned in plastic pots with natural food until the emergence of parasitoids [3].

TABLE I: COLLECTION LOCATIONS

\begin{tabular}{llccc}
\hline \hline Province & Location & Longitude & Latitude & Altitude \\
\hline Anta & Izcuchaca & -71.4506 & -14.0650 & 3672 \\
& Zurite & -72.2661 & -13.4386 & 3472 \\
Calca & Pisac & -71.8467 & -13.4225 & 3225 \\
Canchis & Quiquijana & -71.5394 & -13.8228 & 3628 \\
& Maranganí & -71.1686 & -14.3578 & 3975 \\
Cusco & Kayra & -71.8881 & -13.5417 & 3278 \\
& Perayoc & -71.9781 & -13.5183 & 3392 \\
\multirow{2}{*}{ Urubamba } & Ollantaytambo & -72.2633 & -13.2547 & 3096 \\
\hline \hline
\end{tabular}

\section{Identification}

Specialized taxonomic keys were used for identification [9] - [17], as well as consultations with specialists.

\section{Data Analyses}

The structure of the insect communities for the studied locations are represented in the form of accumulation bars. The Simpson Index (1-D) for each location (PAST software) was determined. A t-test as well as the Pearson correlation coefficient $(\alpha=0.05)$ was performed for related samples taking the beneficial insect species as a variable.

\section{RESULTS}

The wasp Apanteles sp. was found in all the locations studied, followed by Phytomyptera sp. (Fig. 1).

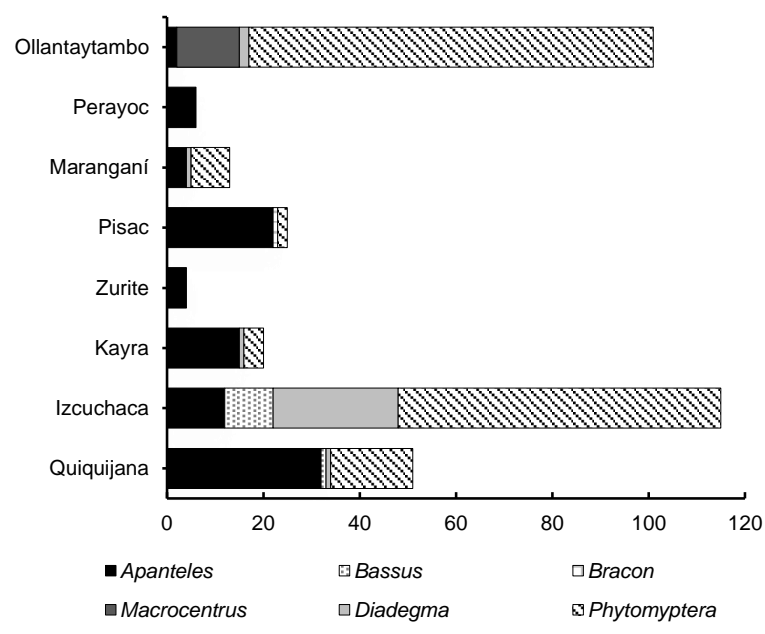

Fig. 1. Structure of beneficial insect communities in quinoa for the studied locations.

The greatest diversity (Simpson 1-D) for parasitoid insects was observed in Izcuchaca (Anta) followed by Quiquijana and Maranganí (Canchis) (Fig. 2).

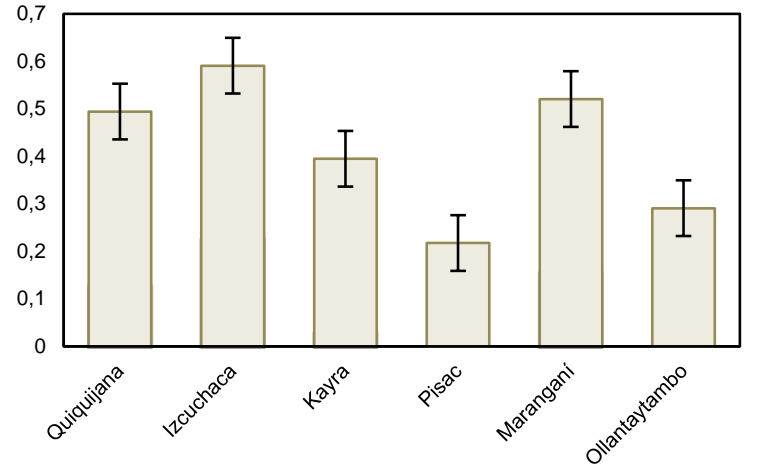

Figure 2. Simpson diversity index (1-D) for the studied locations.

The analysis of related samples shows that there are marked associations between parasitoid species (Table II).

The correlation analysis shows that there are associations, positive and negative, between parasitoid species but a statistically significant and positive correlation is found only between Bassus sp. and Diadegma sp. (Table III).

There is a correlation clearly noticeable between Bassus and Diadegma. The population those species is very similar for each location (Fig. 3a). On the other hand, Apanteles and Phytomyptera showed a lesser correlation between their populations (Fig. 3b).

\section{DISCUSSION}

Results show that the quinoa moth parasitoid complex contains several genera that coincide between locations and countries; among the most important and common genera are Phytomyptera, Apanteles and Diadegma [3], [5], [6], [8], in addition to other genera that could be specific to particular locations.

It should not be overlooked that, in the case of parasitoids, most references are made on genera and not on species, despite the fact that there are comprehensive proposals for biological control based on the natural enemies of the quinoa moth [6], [18].

TABLE II: $P$-VAlue ObTained From The $T$-TEST For Related SAMPLES

\begin{tabular}{|c|c|c|c|c|c|c|}
\hline & Apanteles & Bassus & Bracon & Macrocentrus & Diadegma & Phytomyptera \\
\hline \multicolumn{7}{|l|}{ Apanteles } \\
\hline Bassus & 0.011 n.s. & & & & & \\
\hline Bracon & 0.020 n.s. & $0.4617 *$ & & & & \\
\hline Macrocentrus & 0.059 n.s. & $0.9160 *$ & $0.4438 *$ & & & \\
\hline Diadegma & $2.446 *$ & $0.1017 *$ & $0.2428 *$ & $0.5619 *$ & & \\
\hline Phytomyptera & $0.633 *$ & $0.0786 *$ & $0.0866 *$ & $0.0688 *$ & $0.0990 *$ & \\
\hline
\end{tabular}

TABLE III: PEARSON'S CORRELATION COEFFICIENT FOR BENEFICIAL INSECT SPECIES IN QUINOA CROP

\begin{tabular}{lcccccc}
\hline \hline & Apanteles & Bassus & Bracon & Macrocentrus & Diadegma & Phytomyptera \\
\hline Apanteles & & & & & & \\
Bassus & 0.2249 & & & & & \\
Bracon & 0.6949 & -0.1666 & & & & \\
Macrocentrus & -0.5148 & -0.1666 & -0.1666 & & & \\
Diadegma & 0.1482 & $0.9826 *$ & -0.2395 & -0.0263 & & \\
Phytomyptera & -0.2456 & 0.5682 & -0.2598 & 0.6920 & 0.6913 & \\
\hline \hline
\end{tabular}

*statistical significance, t-value 


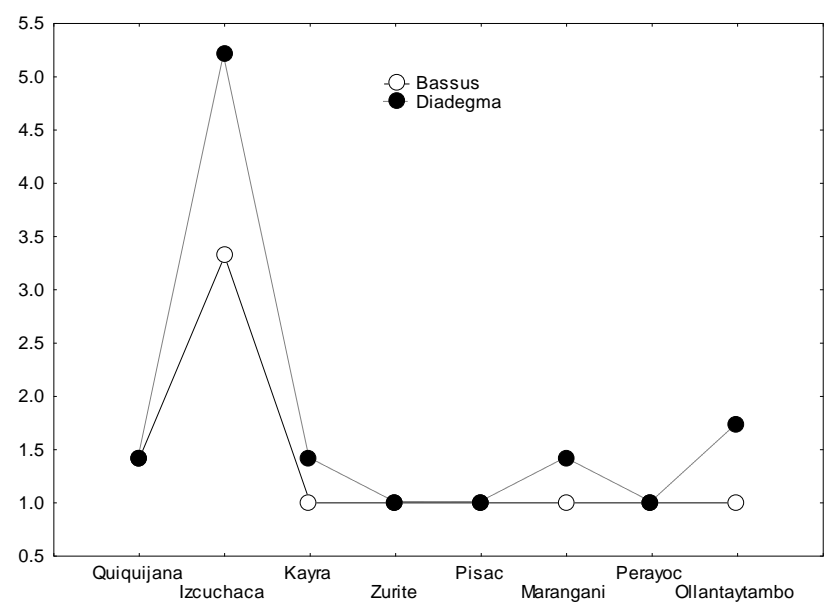

Fig. 3a. Populations of Bassus sp. and Diadegma sp. in the studied locations.

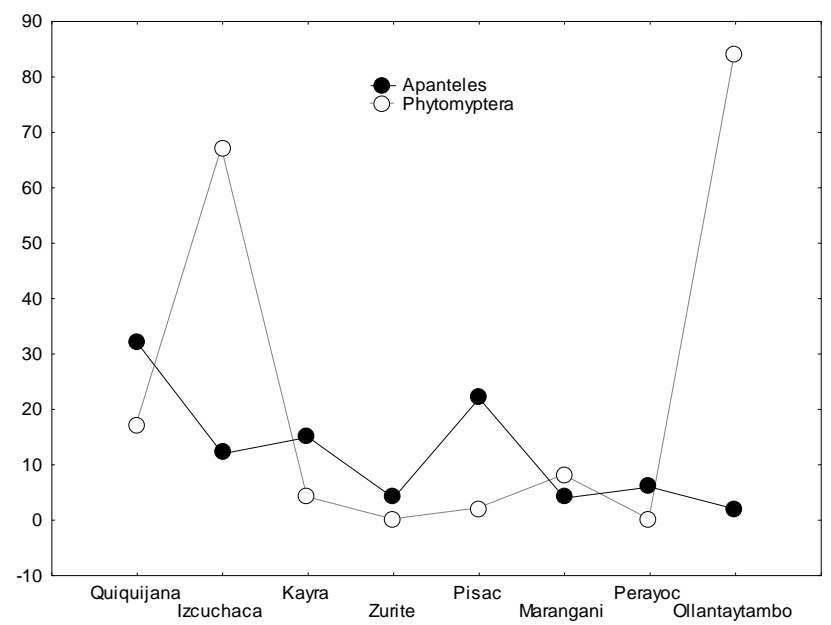

Fig. 3b. Populations of Apanteles sp. and Phytomyptera sp. in the studied locations.

In this sense, it seems appropriate to propose to researchers of quinoa cultivation in South America a collaborative project to achieve the identification at a specific level, both of the parasitoids and of the beneficial insects in general, to generate and update the information on, among other aspects, their taxonomy, behavior, and patterns of distribution.

As has been observed in Bolivia and Peru [3] - [5], there were differences in the levels of parasitoidism in different locations have been found, this study supports that the structure of the beneficial insect communities, in this case parasitoids, depends on location.

Regardless of the locations where the respective assessments have been carried out, the areas suitable for the cultivation of quinoa correspond to high Andean areas that have similar ecological and geographical conditions, which could represent large areas for the management of beneficial insect complexes. This aspect draws attention to the current concepts of Integrated Pest Control. Based on existing data, it is not possible to discuss biological control of the quinoa moth in large areas of production of this crop, but rather, the need to perform diagnoses in different locations to design local strategies based on concrete information of the native insects should be considered, thus reinforcing the proposal to use natural enemies as a resource for the management of the quinoa moth [18].
Furthermore, there is also the fact that different varieties of quinoa are used. As has already been demonstrated, quinoa varieties can have effects on pests and their natural enemies due to their architecture and chemical content [8], [19], but additionally, there is the introduction of new varieties to areas where they were not sown previously [7], thus generating increasingly complex interaction mechanisms [20], [21]. A striking aspect in the use of different varieties of quinoa is the fact that females are attracted by a certain variety, but males are more attracted to the smell derived from females than to the volatile compounds of plants [19].

On the other hand, the analyses carried out (t-test and correlation coefficients) show associations between the species of parasitoids studied. It does not seem likely to expect a numerical relationship between the populations of parasitoids but it can be assumed that, as in the case of Bassus and Diadegma, the high populations found in Anta province may be due to the optimum conditions for quinoa farming and the presence of the quinoa moth in this area, therefore allowing the existence of high populations of these parasitoids. This relationship seems less noticeable in the case of Apanteles sp. and Phytomyptera sp., both considered as the most important parasitoids of the quinoa moth in all cases reported [2] - [5]. In this case, Phytomyptera is clearly more abundant in Izcuchaca (Anta) and Ollantaytambo (Urubamba) which, under the current circumstances, must offer the best conditions for the population development of this genus.

\section{CONCLUSIONS}

The parasitoids Apanteles sp., Bassus sp., Bracon sp., Macrocentrus sp., Diadegma sp., and Phytomyptera sp. have been reported parasitizing quinoa moth larvae: $E$. melanocampta in eight locations of Cusco.

It has been found that the structure of the parasitoid insect communities of quinoa moths is different for the studied locations. The parasitoid communities could be determined by several factors, some of them can be the associated vegetation, altitude, climatic factors and others.

\section{ACKNOWLEDGMENT}

The authors thanks to Anik Levac (The Crees Foundation, Cusco-Peru) for reviewing early drafts of manuscript. Also, Jorge Luis Curo (Southhampton University-UK, and Laboratory of Entomology, Universidad Nacional de San Antonio Abad del Cusco-Peru) helped to improve the manuscript. Both, AL and JLC translated and reviewed the English version.

\section{REFERENCES}

[1] A. Mujica, S. E. Jacobsen. "La quinua (Chenopodium quinoa Willd.) y sus parientes silvestres", in Botánica Económica de Los Andes Centrales, M. Moraes R., B. Øllgaard, L. P. Kvist, F. Borchsenius \& H. Balslev, Ed. Universidad Mayor de San Andrés, La Paz, 2006, pp. 449-457. Available: https://www.academia.edu/31617453/Bot\%C3\%A1nica_Econ\%C3\% B3mica_de_los_Andes_Centrales_2006_pdf. 
[2] C. Rasmussen, A. Lagnaoui, and P. Esbjerg. "Advances in the knowledge of quinoa pests", Food Reviews International, vol. 19, no. 1-2, pp. 61-75, Aug 2003. Available: https://doi.org/10.1081/FRI120018868.

[3] J. F. Costa, E. Yabar-Landa, and E. Gianoli. "Parasitismo sobre Eurysacca melanocampta Meyrick (Lepidoptera: Gelechiidae) en dos localidades de Cusco, Perú", Revista Facultad Nacional de Agronomia, vol. 62, no. 1, pp. 4807-4813, Jun 2009. Available: http://www.scielo.org.co/scielo.php?script=sci_arttext\&pid=S0304$28472009000100008 \& \operatorname{lng}=$ en\&nrm=iso $>$

[4] C. Rasmussen, A. Lagnaoui, and P. Delgado. "Phytomyptera sp. (Diptera: Tachinidae): an important natural control agent of the quinoa moth, Eurysacca quinoae (Lepidoptera: Gelechiidae) in the central Peru", The Tachinid Times, vol. 14, pp. 5-6, January 2001. Available:

https://www.researchgate.net/publication/271214122_Phytomyptera sp_Diptera_Tachinidae_an_important_natural_control_agent_of_the quinoa_moth_Eurysacca_quinoae_Lepidoptera_Gelechiidae_in_the_c entral_Peru.

[5] R. Quispe, R. Saravia, and A. Bonifacio. "Enemigos naturales asociados a las plagas clave del cultivo de quinua (Chenopodium quinoa Willd.) en el Altiplano de Bolivia", presented at IV Quinoa World Congress and I Andean Grains Symposium, Ibarra, Ecuador, July 08-12, 2013.

[6] I. Figueroa, B. Ríos, L. Crespo, R. Saravia, R. Quispe. "Parasitoides de larvas de polilla de la quinua (Eurysacca quinoae P.) perspectiva de control biológico en quinua orgánica". In Congreso Cientifico de la Quinua, M. Vargas (Ed.), AGRIS F01, pp. 359-369, La Paz, Bolivia, June 14-15, $2013 . \quad$ Available: http://www.alimentosargentinos.gob.ar/HomeAlimentos/Cultivos\%20 Andinos/Quinua/Bibliografia\%20Quinua/4\%20OTROS/Memoria\%20 Congreso\%20Cientifico\%20Quinua.pdf.

[7] M. E. Valoy, M. A. Bruno, F. E. Prado, and J. A. González. "Insectos asociados a un cultivo de quinoa en Amaicha del Valle, Tucumán, Argentina", Acta Zoológica Lilloana, vol. 55, no. 1, pp. 16-22, 2011.

[8] E. Yábar, E. Gianoli, E., and E. R. Echegaray. "Insect pests and natural enemies in two varieties of quinua (Chenopodium quinoa) at Cusco, Peru", Journal of Applied Entomology, vol. 126, no. 6, pp. 275-280, July 2002. Available: https://doi.org/10.1046/j.14390418.2002.00664.x.

[9] H. K. Townes and M. Townes. A catalog and reclassification of the Neotropical Ichneumonidae, Memoirs of the American Entomological Institute, vol. 8, pp. 1-366, 1966.

[10] H. K. Townes. The genera of Ichneumonidae, Part 1, Memoirs of the American Entomological Institute, vol. 11, pp. 1-300, 1969.

[11] S. Andersen. "Revision of European species of Phytomyptera Rondani (Diptera: Tachinidae)", Entomologia Scandinavica, no. 19, pp. 43-80, 1988.

[12] R. A. Wharton, P. M. Marsh, and M. J. Sharkey (eds.). Manual of the new world genera of the family Braconidae, Washington, USA: The International Society of Hymenopterists, 1997, pp. 1-456.

[13] M. Sharkey. "Two new genera of Agathidinae (Hymenoptera: Braconidae) with a key to the genera of the New World", Zootaxa, vol. 1185, pp. 37-51, 2006

[14] D. F. Campos and M. J. Sharkey. "Familia Braconidae", in Introducción a los Hymenoptera de la Región Neotropical, F. Fernández and M. J. Sharkey (eds.), Bogotá D.C.: Sociedad Colombiana de Entomología y Universidad Nacional de Colombia, 2006, pp. 331-384. Available: https://doi.org/10.1017/CBO9781107415324.004

[15] E. Ruiz-Cancino. Ichneumonidae (Hymenoptera) del estado de Tamaulipas, México. Serie: Avispas parasíticas de plagas y otros insectos, no. 6, Cd. Victoria, Tamaulipas, México: Editorial Planea, 2010, pp. 1-184. Available: https://www.academia.edu/1993077/Braconidae_Hymenoptera_de_T amaulipas_M\%C3\%A9xico.

[16] Coronado-Blanco, J. M. 2011. Braconidae (Hymenoptera) de Tamaulipas, Serie: Avispas parasíticas de plagas y otros insectos, no. 6, Cd. Victoria, Tamaulipas, México: Editorial Planea, 2011, pp. 1 202.

Available: https://www.researchgate.net/profile/Juana Coronado-

Blanco/publication/260481160_Braconidae_Hymenoptera_de_Tamau lipas_Mexico/links/5419e97f0cf2218008bfa387/Braconidae-

Hymenoptera-de-Tamaulipas-Mexico.pdf.

[17] E. Ruíz-Cancino, J. M. Coronado-Blanco, D. Rafaelevich-Kasparyan and A. Ivanovich-Khalaim. "La diversidad de avispas parasitoides en Tamaulipas: Familia Ichneumonidae", CienciaUAT, vol. 6, no. 1, pp. 14-17, 2011.2 Available: https://www.redalyc.org/articulo.oa?id=4419/441942925002.
[18] M. Valoy, C. Reguilón, and G. Podazza. "The Potential of Using Natural Enemies and Chemical Compounds in Quinoa for Biological Control of Insect Pests", in Quinoa: Improvement and Sustainable Production, K. Murphy \& J. Matanguiiban (Eds.), New Jersey, USA Wiley Blackwell Publishing, 2015, pp. 63-86. Available: https://doi.org/10.1002/9781118628041.ch5.

[19] J. F. Costa,W. Cosio, M. Cardenas, E. Yábar-Landa, E. Gianoli. "Preference of quinoa moth: Eurysacca melanocampta Meyrick (Lepidoptera: Gelechiidae) for two varieties of quinoa (Chenopodium quinoa willd.) in olfactometry assays". Chilean Journal of Agricultural Research, vol. 69, no. 1, pp. 71-78. Available: https://doi.org/10.4067/S0718-58392009000100009.

[20] J. Brodeur and G. Boivin. "Functional Ecology of Immature Parasitoids", Annual Review of Entomology, vol. 49, no. 1, pp. 27-49, January 2004. Available: https://doi.org/10.1146/annurev.ento.49.061703.153618.

[21] T. Tscharntke and R. Brandl. "Plant-Insect Interactions in Fragmented Landscapes", Annual Review of Entomology, vol. 49, no. 1, pp. 405 430, January 2004. Available: https://doi.org/10.1146/annurev.ento.49.061802.123339.

Erick Yábar-Landa was born in Peru, earned his Br Sc. Degree on 1980 from Universidad Nacional de San Antonio Abad del Cusco UNSAAC (Cusco, Peru) and the Biologist diploma on 1980 from Universidad Nacional de San Antonio Abad del Cusco - UNSAAC (Cusco, Peru). His Master degree was obtained on 2000 from Universidad Nacional Agraria La Molina - UNALM (Lima, Peru) and his Doctor in Biological Sciences degree from Universidad Nacional de Cuyo - UNCUYO (Mendoza, Argentina) on 2016.

He worked at Instituto Nacional de Investigación Agraria - INIA (Cusco, Peru) and currently is a Principal Professor of Entomology at Universidad Nacional de San Antonio Abad del Cusco - UNSAAC (Cusco, Peru). He is responsible of The Laboratory of Entomology and his last publications are related to Goniini at Cusco (IDESIA, Chile), Morphology of mouthparts from Premnotrypes (The Biologist, Peru) and Life cycle and life table of Sarconesia chlorogaster (Diptera, Sarcophagidae) (The Biologist, Peru). Currently he is directing a project about the phylogeny and distribution of Andean potato weevils at Peru. His main interest are taxonomy and ecology of Andean insects.

Juan F. Costa was born in Peru, earned his Br. Sc. Degree on 2006 from Universidad Nacional de San Antonio Abad del Cusco - UNSAAC (Cusco, Peru). He obtained his Biologist Diploma on 2010 from Universidad Nacional de San Antonio Abad del Cusco - UNSAAC (Cusco, Peru), and his Master Degree on 2017 from Iberoamerican International University - UNINI, (Arecibo, USA). Currently, he is an associated researcher to Laboratory of Entomology, Faculty of Sciences, Universidad Nacional de San Antonio Abad del Cusco - UNSAAC, and he is working as Junior Manager for Research at Research Vice-chancellor Office from UNSAAC.

His main research field is Entomology including taxonomy, biological control, and ecology. Additionally, Mr. Costa had participated in several research projects including diversity of insects, agrobiodiversity, diversity of birds, mammals, and ecology of high Andean forests. 